\title{
MONIKA POPOW
}

Uniwersytet im. Adama Mickiewicza

w Poznaniu

\section{GLOBALNA PÓŁNOC I GLOBALNE POŁUDNIE W DYSKURSIE EDUKACYJNYM. KRYTYCZNA ANALIZA TREŚCI PODRĘCZNIKÓW SZKOLNYCH}

\begin{abstract}
Popow Monika, Globalna Pótnoc i Globalne Południe w dyskursie edukacyjnym. Krytyczna analiza treści podręczników szkolnych [Global North and South in Educational Discourse. Critical Analysis of School Textbooks Content]. Studia Edukacyjne nr 35, 2015, Poznań 2015, pp. 251-273. Adam Mickiewicz University Press. ISBN 978-83-232-2904-9. ISSN 1233-6688. DOI: 10.14746/se.2015.35.14

The aim of my paper is to analyze the representations of Global North and Global South, presented in geography textbooks in grammar school. First, the concept of global education is presented. Subsequently, representations of North and South and its inhabitants are reconstructed and analyzed. The method used is that of critical discourse analysis. Simultaneously, meanings of reconstructed representations are interpreted in a broad social and cultural context.
\end{abstract}

Key words: global education, critical discourse analysis, geography, textbooks

Celem niniejszego tekstu jest analiza krytyczna treści podręczników szkolnych do geografii, pod kątem przedstawienia w nich wizerunków krajów Globalnego Południa oraz Globalnej Północy¹.

Myślenie o świecie podzielonym na obszary bardziej i mniej rozwinięte ma swoje korzenie w $\mathrm{XV}$ wieku, od rozpoczęcia zamorskich wypraw Europejczyków. To ówczesne, a kontynuowane również w późniejszych epo-

1 Inspiracją dla powstania niniejszego tekstu był mój udział w dwóch projektach badawczych: „Gender w podręcznikach”, realizowanym w ramach programu „Obywatele dla demokracji”, finansowanym z Funduszy EOG, pod kierownictwem Iwony Chmury-Rutkowskiej, Macieja Dudy, Marty Mazurek i Aleksandry Sołtysiak-Łuczak oraz, jako konsultant metodologiczny, w ramach komponentu analizy podręczników w projekcie „Obywatelski monitoring polskiej współpracy rozwojowej”, realizowanym przez Grupę Zagranica. 
kach, rozumienie świata jako nieodkrytej przestrzeni, która może zostać podzielona między swoich odkrywców, na wiele stuleci ukształtowało europejskie pojmowanie polityki, ekonomii i kultury, co dobitnie w swoich analizach ukazali teoretycy postkolonializmu².

Wpłynęło ono również na sposób, w jaki opisywany jest świat, w tym na proces dyskursywnego tworzenia nierówności pomiędzy pewnymi obszarami geograficznymi i kulturowymi. Waltera D. Mignolo pisze w tym kontekście o roli, jaką w kreowaniu globalnego obrazu świata odegrała kartografia oraz prawo międzynarodowe, posługujące się globalnym myśleniem linearnym. Myślenie to jest efektem eurocentrycznego podziału świata na Wschód i Zachód, Północ i Południe oraz Pierwszy, Drugi i Trzeci Świat, a następnie wykreowanie tego podziału na ontologię, mającą wzmacniać dominującą i centralizującą rolę Europy, a następnie Stanów Zjednoczonych, $\mathrm{w}$ drugiej połowie $\mathrm{XX}$ wieku posłużył do usprawiedliwiania misji rozwoju i modernizacji3 ${ }^{3}$.

Koncepcja istnienia Pierwszego, Drugiego i Trzeciego Świata ukształtowała się w epoce zimnowojennej. Wraz z upadkiem systemu komunistycznego podział ten zaczął tracić sens. Ponadto, koncepcja ta była szeroko krytykowana ze względu na wartościujący charakter, odnoszący się do krajów rozwijających się, stąd pojawienie się określeń Globalna Północ i Globalne Południe, stosowanych $\mathrm{w}$ odniesieniu do tak zwanych krajów leżących na półkuli południowej, za wyjątkiem Australii i Nowej Zelandii. Określenia Globalnej Północy i Globalnego Południa uważane są obecnie za bardziej neutralne ${ }^{4}$.

Kwestia, którą chciałabym się zająć w niniejszym artykule, powiązana jest $\mathrm{z}$ kilkoma obszarami badawczymi w badaniach społecznych. Zależności globalne, poprzez które rozumiem kulturowe, ekonomiczne i polityczne relacje pomiędzy różnymi częściami świata, pozostają w kręgu zainteresowań pedagogiki, między innymi pedagogiki międzykulturowej, krytycznej, emancypacyjnej, czy ekologicznej. Przede wszystkim jednak wizerunki poszczególnych obszarów świata globalnego wpisują się w obszerny nurt badań nad globalizacją, a więc badaniami nad procesami czy praktykami zachodzącymi w globalizującym się świecie, reprezentowanymi między

2 Por. E. Said, Orientalizm, Poznań 2005.

${ }^{3}$ W.D. Mignolo, The North of the South and the West of the East. A Provocation to the Question, http://www.ibraaz.org/essays/108/ [dostęp: 23.01.2015].

${ }^{4}$ G. Świderek, O edukacji globalnej i zróżnicowanym świecie, http://www.globalna.edu.pl/ globalnie1/ [dostęp: 26.01.2015]. 
innymi przez Zygmunta Baumana5 ${ }^{5}$ Zbyszko Melosika6, czy Przemysława Grzybowskiego ${ }^{7}$.

Definiując pojęcie globalizacji, Detlef Muller-Mahn zauważa, że charakteryzuje się ona

różnorodnością powiązań i przeplatania się wzajemnych relacji między państwami, które współcześnie stanowią system światowy. Sprawia ona, że wydarzenia, decyzje i działania podejmowane w jednej części świata wpływają w dużym stopniu na to, co dzieje się w innych, odległych częściach świata8 ${ }^{8}$.

Wydaje się, że w tym kontekście niezwykle ważna, również dla badań pedagogicznych, w tym badań nad procesami tożsamościowymi, pozostaje kwestia relacji pomiędzy różnymi aktorami świata globalnego, a także ich wzajemne o sobie wyobrażenia, przekonania i stereotypy. Tożsamość w świecie globalnym kształtuje się bowiem w relacji do szeregu kontekstów, $\mathrm{w}$ tym $\mathrm{w}$ ramach globalnych relacji makroekonomicznych i kulturowych. Generowane przez nie nowe struktury, w tym związane z migracjami i globalnymi podziałami pracy, z jednej strony sprawiają, że świat staje się przysłowiową "globalną wioską", z drugiej jednak tworzą szereg globalnych nierówności społecznych, co wpływa na powstawanie określonych wzorów tożsamościowych.

Problematyką tą w sposób szczególny zainteresowana jest edukacja globalna, której koncepcję oraz rozwój chciałabym przedstawić poniżej.

\section{Edukacja globalna jako zmiana}

Idea edukacji globalnej pojawiła się $\mathrm{w}$ okresie transformacji ustrojowej wraz z takimi prądami w pedagogice, jak pedagogika międzykulturowa, czy krytyczna. Obecnie edukacja globalna najczęściej jest obecna w kontekście edukacji międzykulturowej oraz edukacji dla zrównoważonego rozwoju, który pojmowany może być również w kontekście globalnym. Zwolennicy takiego podejścia widzą zatem związek pomiędzy edukacją globalną a kształtowaniem świadomych postaw konsumenckich oraz wiedzy na te-

${ }^{5}$ Z. Bauman, Globalizacja. I co z tego dla ludzi wynika, Warszawa 2000.

${ }^{6}$ Z. Melosk, Teoria i praktyka edukacji wielokulturowej, Kraków 2007.

7 P. Grzybowski, Tożsamość globalna - kłopoty z poszukiwaniem siebie, [w:] Tożsamość osobowa a tożsamości społeczne, red. T. Bajkowski, K. Sawicki, Białystok 2001.

8 D. Müller-Mahn, Ägyptische Migranten in Paris. Transnationale Migration und die Relativierung des Lokalen, Geographische Rundschau, 2002, 10(54), cyt. za: J. Kozielska, Poakcesyjne migracje zarobkowe. Kontekst teoretyczno-empiryczy. Wsparcie społeczne, Poznań 2014, s. 19. 
mat zmian klimatu, pozyskiwania energii, a także produkcji i handlu żywnościąa.

Elementy edukacji globalnej zostały wpisane do nowej podstawy programowej w 2008 roku. Najwięcej jej treści realizowanych jest w ramach przedmiotu geografia. W komentarzu do nowej podstawy programowej przedmiotu geografia w szkole gimnazjalnej przeczytać możemy między innymi:

Geografia jak żadna inna nauka powinna uczyć o kulturowym zróżnicowaniu świata, pozwalając zrozumieć specyficzne cechy i rolę innych narodów i grup w rozwoju cywilizacyjnym świata (...). Przedmiotem badań i dydaktyki geografii jest więc zarówno tradycyjna perspektywa regionalna i lokalna, jak i globalne relacje, powiązania i procesy. System powiązań oznacza tu przepływy (wymianę) dóbr (towarów), pieniędzy, informacji, ludzi między bliskimi i odległymi miejscami10.

Widoczne jest tu wyraźne dążenie do ukazania edukacji geograficznej w perspektywie zarówno regionalnej oraz globalnej, w tym relacji ekonomicznych. Takie też zadanie stawiają przed sobą podręczniki zgodne z nową podstawą programową.

Włączanie edukacji globalnej do nowej podstawy programowej stanowi ciekawy przykład współpracy pomiędzy Ministerstwem Edukacji Narodowej a sektorem organizacji pozarządowych, zajmujących się międzynarodową współpracą rozwojową, pomocą humanitarną i edukacją globalną. W efekcie procesu międzysektorowego, serii spotkań przedstawicieli organizacji oraz MEN, zainicjowanych podczas konferencji „Rozwój edukacji globalnej w Polsce - perspektywy współpracy międzysektorowej" w 2009 roku, przyjęto m.in. cel mówiący o

uwzględnieniu treści edukacji globalnej w podręcznikach szkolnych, w tym podniesieniu świadomości miejsca edukacji globalnej w podstawie programowej wśród wydawców podręczników i ich autorów oraz podniesieniu świadomości na temat miejsca edukacji globalnej w podstawie programowej wśród rzeczoznawców i rzeczoznawczyń11.

Edukacja globalna, której definicję i cele przyjęto w ramach procesu międzysektorowego, definiowana jest w następujący sposób:

${ }^{9}$ G. Świderek, Postaw na rozwój. Zrównoważony! Scenariusze zajęć dla uczniów klas IV-VI szkót podstawowych, Łódź 2013, s. 7.

${ }^{10}$ E. Szkurłat, Geografia w gimnazjum, [w:] Komentarz do podstawy programowej, [w:] Podstawa programowa z komentarzami, t. 5, Warszawa 2008, s. 181.

${ }^{11}$ E. Kielak, Edukacja globalna w podręcznikach do geografii. Raport $z$ analizy wybranych podręczników szkolnych pod kątem zatożeń edukacji globalnej, Warszawa 2014, s. 4. 
Edukacja globalna to część kształcenia obywatelskiego i wychowania, która rozszerza ich zakres przez uświadamianie istnienia zjawisk i współzależności globalnych. Jej głównym celem jest przygotowanie odbiorców i odbiorczyń do stawiania czoła wyzwaniom dotyczącym całej ludzkości. Przez współzależności rozumiemy wzajemne powiązania i przenikanie systemów kulturowych, środowiskowych, ekonomicznych, społecznych, politycznych i technologicznych ${ }^{12}$.

Do celów edukacji globalnej zalicza się:

tłumaczenie przyczyn i konsekwencji opisywanych zjawisk, przedstawianie perspektywy Globalnego Południa, przedstawianie świata, jako złożonego i dynamicznie zmieniającego się systemu, kształtowanie krytycznego myślenia i zmiana postaw, przełamywanie istniejących stereotypów i uprzedzeń, ukazywanie wpływu jednostki na globalne procesy i wpływu globalnych procesów na jednostkęi13.

Wydaje się, że współcześnie mamy do czynienia z potrzebą rozwinięcia takiego podejścia do edukacji globalnej, które uwzględni wpływ zmieniających się współczesnych kontekstów mikro- i makroekonomicznych. Edukacja globalna wydaje się charakteryzować przede wszystkim zmiennością i koniecznością nieustającej rewizji swoich podejść. Zależy w ogromnym stopniu od aktualnych globalnych układów sił kulturowych i ekonomicznych. Czy zatem edukacja globalna powinna pomieścić zarówno kwestie związane z globalnymi nierównościami społecznymi, kryzysem ekologicznym i ekologią polityczną, kryzysem tożsamości i narastającymi tendencjami nacjonalistycznymi, które dotykają już nie tyko Europę, ale też cały globalny świat? Zbigniew Kwieciński zauważa w tym kontekście, że pedagogika stoi przed niemałym problemem:

$\mathrm{W}$ pedagogice i w praktyce edukacyjnej obecne są skrajne odpowiedzi na pytanie o możliwości edukacji co do rozwiązywania globalnych problemów przyszłości. $Z$ jednej strony - nierzadko przyjmowana jest postawa adresowania do edukacji wszystkich beznadziejnych problemów, przed którymi stoi nasz świat. (...) Z drugiej strony - mamy do czynienia z pedagogicznym redukcjonizmem, który polega na rezygnacji z wszelkiej szerszej perspektywy wychowanka niż jego osobista i dotycząca jego bezpośrednich kontaktów społecznych, niż interpersonalna oraz rezygnacji $\mathrm{z}$ wszelkiej innej orientacji niż aktualistyczna14.

12 J. Bowżyk i inni, Edukacja globalna na zajęciach wiedzy o społeczeństwie, Warszawa 2014, s. 3.

${ }^{13}$ E. Kielak, Edukacja globalna w podręcznikach do geografii, s. 10.

${ }^{14}$ Z. Kwieciński, Edukacja do globalnego przetrwania i rozwoju, [w:] Tropy-ślady-próby. Studia i szkice z pedagogii pogranicza, red. Z. Kwieciński, Poznań-Olsztyn 2000, s. 235. 
Rozwiązania tego problemu upatruje się w różnych nurtach. W tym kontekście wymieniane jest między innymi promowanie wartości i krytyczne myślenie ${ }^{15}$, czy też wprowadzenie standardów edukacji globalnej ${ }^{16}$.

W badaniach zagranicznych nad edukacją globalną dominuje perspektywa globalnej edukacji obywatelskiej, która rozumiana jest jako przygotowywanie uczniów do pełnienia aktywnej roli, zarówno w kontekście lokalnym, w swoim regionie, jak i globalnym. Szczególną rolę odgrywa kształtowanie postaw akceptacji dla różnorodności i szacunku dla praw człowieka, a także kształcenia $\mathrm{w}$ duchu współpracy i pokojowego rozwiązywania problemów. Wśród obszarów tak rozumianej edukacji wymienia się: kształcenie w duchu takich wartości, jak empatia, szacunek dla drugiego człowieka oraz kształcenie umiejętności współpracy, umiejętności interpersonalnych, komunikacji, pracy zespołowej; edukację na rzecz pokoju; edukację na rzecz praw człowieka; edukację obywatelską; edukację humanitarną; reformowanie historii edukacji; wymiar psychospołeczny, do którego zalicza się skupienie na psychospołecznych potrzebach dziecka oraz różnego rodzaju inne podejścia wspierające dziecko $\mathrm{w}$ radzeniu sobie ze stresem oraz rozwijające zachowania prospołeczne ${ }^{17}$.

Tego rodzaju podejścia, które można nazwać aktywistycznymi, stawiają przed edukacją globalną przede wszystkim rozwój globalnej odpowiedzialności. Jest ona tutaj praktyką włączania i angażowania. Podobne podejścia możemy znaleźć $\mathrm{w}$ polskiej pedagogice, na przykład w pracach Zbyszko Melosika, który zauważa, że celem edukacji globalnej powinny być dialog międzykulturowy, orientacja na zmianę, antycypacja i uczestnictwo, które mają pozwolić na identyfikację jednostki z całą ludzkością ${ }^{18}$.

Rozwijając ten wątek, należy wspomnieć o krytycznej edukacji globalnej, która jest podejściem zorientowanym na prawa człowieka, w tym prawa podstawowe, takie jak prawo do życia, bezpieczeństwa, prawo do życia $\mathrm{w}$ warunkach pokoju oraz w czystym środowisku. Nurt ten zyskuje coraz większą aktualność, zwłaszcza wobec wzrastającej liczby lokalnych konfliktów zbrojnych. Kształcenie ma się tu odbywać w duchu globalnego krytycznego obywatelstwa (critical global citizenship) ${ }^{19}$. Centralnymi pojęciami są

${ }^{15}$ P. Warych, Edukacja globalna wobec problemów wspótczesnego świata, Homines Homnibus, 2012, 8, s. 19-32.

16 Por. E. Kielak, Edukacja globalna w podręcznikach do geografii; J. Bowżyk i inni, Edukacja globalna na zajęciach wiedzy o społeczeństwie.

17 Education for Global Citizenship, Qatar 2012, s. 16-17.

18 Z. Melosik, Edukacja globalna: nadzieje i kontrowersje, [w:] Wprowadzenie do pedagogiki: wybór tekstów, red. T. Jaworska, R. Leppert, Kraków 1996, s. 55.

19 V. Andreotti, Soft versus Critical Global Citizenship Education, Global Citizenship, 2006, 3, http://www.developmenteducationreview.com/issue3-focus4 [dostęp: 26.01.2015]. 
władza, głos oraz różnica. Krytyczne globalne obywatelstwo odwołuje się do tradycji Paolo Freirego, podnosząc wagę alfabetyzacji krytycznej, rozumianej szeroko jako umiejętność odczytywania świata, krytycznego zaangażowania oraz refleksyjności, czyli analizy i krytyki relacji pomiędzy własną perspektywą, językiem, władzą, grupami społecznymi i praktykami społecznymi samych uczących się. Perspektywa krytyczna, jak zaznacza Vanessa Andreotti, będzie zatem oznaczać stworzenie perspektywy dla refleksji nad własnym miejscem w strukturze społecznej oraz miejscem własnych Innych, a w konsekwencji nad lokalnymi oraz globalnymi relacjami władzy, podziałami pracy oraz zasobów ${ }^{20}$.

Wydaje się jednak, że wzorów postaw, zachowań, czy umiejętności krytycznego myślenia również $\mathrm{w}$ skali globalnej nie da się przeprowadzić bez dekonstrukcji dotychczasowych wzorców wypowiedzi na temat relacji globalnych, odzwierciedlających często społeczne stosunki władzy, wyrażone poprzez dominujące dyskursy. Dekonstrukcja dyskursywnych relacji władzy jest rodzajem pracy, wynikającej z przekonania, że współczesne społeczeństwa podlegają gwałtownym przemianom, a rzeczywistość społeczna dynamicznie konstruowana jest $\mathrm{w}$ procesie komunikacji21. $\mathrm{W}$ ten nurt chciałabym wpisać moją pracę.

\section{Metodologia badania}

Do analizy wyznaczony został przedmiot geografia na poziomie gimnazjalnym, jako że w jego podstawie programowej znajduje się najwięcej treści z zakresu edukacji globalnej.

Poddane ocenie podręczniki zostały wybrane na podstawie analizy stron internetowych szkół gimnazjalnych w Poznaniu. Intencją doboru próby było określenie najczęściej używanych podręczników, a więc takich, z którymi poznańscy uczniowie realnie mają kontakt. W ten sposób do analizy wybrano następujące podręczniki:

1. Puls Ziemi 1 - podręcznik do geografii dla klasy pierwszej gimnazjum, Roman Malarz, Wydawnictwo Nowa Era 2014;

2. Puls Ziemi 2 - podręcznik do geografii dla klasy drugiej gimnazjum, Bożena Dobosik, Adam Hibszer, Józef Soja, Wydawnictwo Nowa Era 2012;

20 Tamże.

${ }^{21}$ A. Grzymała-Kazłowska, Socjologicznie zorientowana analiza dyskursu na tle wspótczesnych badań nad dyskursem, Kultura i Społeczeństwo, 2004, 1(48), s. 13-34. 
3. Puls Ziemi 3 - podręcznik do geografii dla klasy trzeciej gimnazjum, Roman Malarz, Wydawnictwo Nowa Era 2014;

4. Planeta Nowa 1 - podręcznik do geografii dla klasy pierwszej gimnazjum, Roman Malarz, Wydawnictwo Nowa Era 2014;

5. Planeta Nowa 2 - podręcznik do geografii dla klasy drugiej gimnazjum, Dawid Szczypiński, Mirosław Wójtowicz, Wydawnictwo Nowa Era 2013;

6. Planeta Nowa 3 - podręcznik do geografii dla klasy trzeciej gimnazjum, Roman Malarz, Wydawnictwo Nowa Era 2014

7. ABC Geografii 1 - Hanna Młynkowiak, Aleksandra Pietrzak, Zofia Tomkiewicz, Wydawnictwo ABC 2010;

8. ABC Geografii 2 - Hanna Młynkowiak, Aleksandra Pietrzak, Zofia Tomkiewicz, Wydawnictwo ABC 2010;

9. ABC Geografii 3 - Hanna Młynkowiak, Aleksandra Pietrzak, Zofia Tomkiewicz, Wydawnictwo ABC 2012.

Zaprezentowane poniżej badanie przeprowadzono za pomocą jakościowej analizy treści podręczników. Ze względu na rozkład treści w nowej podstawie programowej, analiza $\mathrm{w}$ największym zakresie objęła podręczniki do klasy drugiej, jako że w nich umieszczone są treści z zakresu geografii społeczno-ekonomicznej oraz relacji globalnych.

Przyjęte narzędzie badawcze zakładało wytypowanie $\mathrm{w}$ treści podręczników jednostek zorganizowanych według nazw krajów, kontynentów oraz ich mieszkańców (w tym nazw własnych i nazwisk postaci), a następnie przeanalizowanie ich według klucza kategoryzacyjnego, zorganizowanego według kategorii związanych z rolami pełnionymi przez mieszkańców, kraje i kontynenty, charakterystykami fizycznymi oraz psychicznymi krajów i kontynentów oraz ich mieszkańców, jak też kategorią dotyczącą ważności, czyli częstotliwości występowania oraz ekspozycji. Analizie podlegały całe fragmenty, to jest dające się logicznie wyodrębnić jednostki, wraz z otoczeniem, a więc towarzyszącymi im ilustracjami, podpisami, czy uwagami na marginesach. Metoda ta pozwala na dokonanie rzetelnego opisania osób i rzeczy zarówno w jednostkach tekstu, jak i na ilustracjach. Opracowane przeze mnie narzędzie badawcze zainspirowane zostało badaniem Doroty Pankowskiej: Obraz systemu ról ptciowych w podręcznikach szkolnych - analiza porównawcza22.

Jakościową analizę tekstu łączę w mojej pracy z krytyczną analizą dyskursu, która pozwala nie tylko na zrekonstruowanie przedstawianych wize-

22 D. Pankowska, Obraz systemu ról płciowych w podręcznikach szkolnych - analiza porównawcza, Przegląd Badań Edukacyjnych, 2005, 1. 
runków, ale również na opisanie tego, w jaki sposób wpływają one na nasze wyobrażenie o świecie oraz przekonania ${ }^{23}$. Ten etap analizy prowadzony był na wyodrębnionych wcześniej jednostkach tekstu.

Zastosowane przeze mnie podejście wpisuje się w tak zwaną miękką, opisową, odmianę analizy dyskursu. Z uwagi na potrzebę zintegrowania w ramach analizy różnych obszarów - zarówno używanego języka, jak i nadawanych znaczeń oraz społecznego kontekstu społeczno-ekonomicznego, w którym zanurzony jest analizowany materiał - zastosowałam, za Ann Chapman, podejście społeczno-semiotyczne, które koncentruje się na interakcjach społecznych, a więc na tym, w jaki sposób konstruowane są systemy znaczeń. Pozwala ono analizować język w odniesieniu do innych systemów semiotycznych, takich jak konkretna dyscyplina, w tym wypadku geografia i ekonomia, i przyjrzeć się, w jaki sposób znaczenia konstruowane są w ich polach ${ }^{24}$.

Poniżej zostaną przedstawione uogólnione wnioski z analizy, poddane już wstępnej teoretyzacji oraz interpretacji.

\section{Globalna Północ i Globalne Południe. Pomiędzy binarnymi opozycjami}

Na podstawie jakościowej analizy tekstu wybranych podręczników do geografii, z użyciem kategorii związanych z rolami pełnionymi przez mieszkańców, kraje i kontynenty, charakterystykami fizycznymi oraz psychicznymi krajów i kontynentów oraz ich mieszkańców, a także kategorią dotyczącą częstotliwości występowania oraz ekspozycji, można określić, że analizowane podręczniki odnoszą się do tematyki Globalnej Północy i Globalnego Południa najczęściej w kontekście relacji ekonomicznych oraz rozwoju gospodarczego. Mimo że mogłoby się wydawać to oczywiste w świetle podstawy programowej, uwagę zwraca kontekst przedstawień.

Krytyczna analiza wizerunków Globalnej Północy i Globalnego Południa pokazuje, że obraz świata globalnego w podręcznikach do geografii konstruowany jest z wyraźną dominacją dyskursu rozwoju cywilizacyjnego. Świat $\mathrm{w}$ analizowanych podręcznikach przedstawiony został w sposób binarny - występuje zatem część rozwinięta, charakteryzująca się wysokim

${ }^{23}$ T. van Dijk, Principles of critical discourse analysis, Discourse \& Society, 1993, 4, s. 1021, cyt. za: B. Jabłońska, Krytyczna analiza dyskursu w świetle założeń socjologii fenomenologicznej (dylematy teoretyczno-metodologiczne), Przegląd Socjologii Jakościowej, 2013, 9, 1, s. 51.

24 A. Chapman, Reflections on a social semiotic approach to discourse analysis in educational research, [w:] Qualitative Educational Research in Education, London 2003, s. 153. 
poziomem rozwoju społecznego i ekonomicznego (,kraje wysoko uprzemysłowione", ,kraje rozwinięte", "nowoczesne gospodarki”) oraz część rozwijająca się, określana jako „kraje rozwijające się" czy też „kraje kontrastów.

W kontekście tym spójrzmy również na poniższe przykłady:

Prymitywne rolnictwo i częste susze powodują, że wiele krajów nie jest w stanie zapewnić odpowiedniej ilości żywności wzrastającej liczbie swoich mieszkańców. $(\mathrm{PN} 2,18)$

Rolnictwo, często prymitywne, jest źródłem utrzymania wielu mieszkańców Afryki. $(\mathrm{AG} 2,72)$

Cytowane fragmenty są nacechowane wartościująco. Określenie "prymitywny" zostało współcześnie wyeliminowane ze słownika antropologicznego jako „odnoszące się do relatywnych osiągnięć albo wartości różnych kultur ${ }^{25}$. Ponieważ określenia tego typu najczęściej używane są $\mathrm{w}$ znaczeniu kontrastu wobec "krajów rozwiniętych", uznawane są za manifestację zachodniego etnocentryzmu. Kwestia ta, niemalże od początku ich istnienia, szeroko poruszana jest w studiach postkolonialnych. W książce Orientalizm, uznawanej za dzieło założycielskie postkolonializmu, Edward Said zrekonstruował dyskursywne praktyki kreowania Orientu jako miejsca kulturowo różnego, podrzędnego wobec Zachodu, a więc, jak pokazał autor, ukazywanego właśnie jako prymitywny i dziki ${ }^{26}$. Kwestia rewizji etnocentryczności nauki i zmiany jej słownika nie znalazła odzwierciedlenia w analizowanym materiale. $W$ podręcznikach ten typ dyskursu najczęściej dotyczy rozwoju ekonomicznego, utożsamianego z rozwojem cywilizacyjnym:

A to ciekawe... Wielu naukowców, wybitnych i uznanych na świecie specjalistów z różnych dziedzin, to właśnie Hindusi. Tymczasem aż $40 \%$ indyjskiego społeczeństwa nie potrafi nawet czytać ani pisać, gdyż nie ma dostępu do edukacji. (PN 2, 129)

Przytoczony fragment jest charakterystyczny dla opisu stopnia rozwoju Globalnego Południa. Podstawowy zabieg stanowi tu skontrastowanie symbolizujących rozwój naukowców z analfabetyzmem. Za sprawą tego zabiegu naukowcy wywodzący się z Indii mogą być postrzegani jako zjawisko nietypowe, czy nienaturalne dla tego kraju. Ponadto, umieszczenie tej informacji w dziale ciekawostek sprawia, że nadawany jest jej wymiar egzotyczności, niezwykłości, a nawet żartobliwości.

${ }^{25}$ M.E. Sapiro, Relatywizm kulturowy i przysztość antropologii kulturowej, [w:] Badanie kultury. Elementy teorii antropologicznej. Kontynuacje, red. E. Nowicka, M. Kempny, Warszawa 2004, s. 28.

${ }^{26}$ E. Said, Orientalizm. 
Podobny zabieg możemy znaleźć w innym podręczniku w opisie Stanów Zjednoczonych oraz Brazylii. Kraje te, wybrane jako największe na kontynentach Ameryki Północnej i Południowej, zostały porównane i skontrastowane. W zestawieniu tym jednak tylko w Brazylii występują problemy społeczne oraz konieczność pokazania, że kraj ten ma "drugie oblicze” (PZ2, 63). Stany Zjednoczone zostały natomiast przedstawione jako kraj osiągnięć cywilizacyjnych, w którym problemy społeczne nie występują.

Co ciekawe, dyskurs o dominacji cywilizacyjnej ma również zastosowanie w odniesieniu do różnych części Europy. W prezentacji Ukrainy i Białorusi dominują na przykład obrazy wsi. Kultura wsi stanowi jedyne środowisko, w jakim przedstawiane są kobiety z Europy Wschodniej, portretowane najczęściej w strojach ludowych. Ciekawym przykładem jest tekst dotyczący gospodarki Białorusi, który został zilustrowany zdjęciem kobiet pracujących ręcznie w polu. Klęczą one na ziemi i zbierają ziemniaki (PN2, 218).

Ubóstwo jako problem społeczny $\mathrm{w}$ analizowanych podręcznikach przypisywane jest przede wszystkim Globalnemu Południu. We wszystkich podręcznikach tylko $\mathrm{w}$ odniesieniu do tego obszaru stosowane jest uwypuklanie kontrastów społecznych, na przykład:

Przemysł wysokiej technologii, np. elektroniczny, biotechnologiczny, lotniczy i kosmiczny, a na przeciwległym biegunie zacofanie, oparte na prymitywnych metodach gospodarowania rolnictwo. Tak właśnie wygląda indyjska gospodarka na początku XXI wieku. (PZ2, 122)

Miasta rozrastają się w sposób niekontrolowany. Rosną dzielnice nędzy - slumsy. W przeludnionych miastach brakuje pracy i mieszkań, dlatego większość nowo przybyłej ludności to ludzie bezdomni, sypiający na chodnikach i zajmujący się żebractwem. (AG, 117)

Ubóstwo na Globalnym Południu opisywane jest w sposób oddziałujący na wyobraźnię:

Do wielkich społecznych problemów Indii należy olbrzymia, niewyobrażalna wręcz bieda. Celem życia biedaków jest przeżycie do następnego dnia i zdobycie minimalnej ilości pożywienia, aby nie umrzeć z głodu. W wielkich miastach, zwłaszcza w Kalkucie, rosną dzielnice nędzy, w których ludzie śpią na ulicach, głodują, nie mają żadnych środków do życia. Liczbę biedaków szacuje się na około 300 milionów. $(\mathrm{AG} 2,147)$

W przytoczonym fragmencie widać, że bieda Południa opisana jest za pomocą takich określeń ekspresyjnych, jak „olbrzymia”, „niewyobrażalna”. Zastosowanie zabiegu personifikacji biedy poprzez stworzenie postaci biedaków oraz opowieści o ich życiu, łącznie z określeniem celu tego życia, po- 
budza wyobraźnię, a do tego bazuje na emocjach. Opis tego typu, będący generalizacją, potęguje wręcz stereotypowe wyobrażenia na temat ubóstwa w Indiach.

Istotną rolę w opisach biedy odgrywa również dyskurs naukowy. Dużą wagę przywiązuje się do różnego rodzaju wskaźników, będących częścią ekonomicznego oraz socjologicznego dyskursu naukowego. Wskaźniki takie, jak PKB czy HDI (Human Development Index) podawane są w formie wykresów i tabel. Można wysnuć przypuszczenie, że na poziomie nadawania znaczenia, ich istotną funkcją jest unaukowienie i obiektywizacja treści, które znajdują się $\mathrm{w}$ ich otoczeniu, a ich funkcję w tym kontekście można interpretować jako wskaźniki ucywilizowania. Użycie wskaźników i danych liczbowych unaukowia wiedzę na temat problemów społecznych. Na przykład, w podręczniku Planeta Nowa 2 rozdział „Problemy mieszkańców Afryki" ilustrowany jest dwoma mapami przedstawiającymi cały kontynent afrykański, z których jedna prezentuje odsetek ludności niedożywionej w 2011 roku, a drugi - wskaźnik rozwoju społecznego (HDI). Mapom towarzyszy zdjęcie przedstawiające kobietę i dziecko, które jest niekompletnie ubrane i bose, czerpiących wodę z prowizorycznego zbiornika na pustyni. Ten sposób przedstawienia sprawia, że informacje dotyczące negatywnych zjawisk społecznych, które mogą być reprezentatywne dla pewnych obszarów w Afryce, jednak nie dla całego kontynentu, zostają uogólnione na poziom całego kontynentu oraz co więcej - nabierają znaczenia obiektywnej wiedzy naukowej, która jest niepodważalna, gdyż uzasadniona liczbowo.

Ta swoista diagnostyka stanu społeczeństw Globalnego Południa wsparta jest politycznymi wskaźnikami rozwoju, takimi jak formy porządku politycznego lub militarnego:

Państwa o ustabilizowanej sytuacji politycznej, oferujące dużą ilość atrakcji turystycznych, są licznie odwiedzane przez zamożnych obcokrajowców. (PN2, 20)

Tylko nieliczne afrykańskie państwa mają kompletnie umundurowaną armię. (PZ2, 21)

Rolę wskaźników ucywilizowania może również pełnić rozwój infrastruktury. W podręczniku Puls Ziemi 2, rozdział pod tym samym tytułem „Problemy mieszkańców Afryki” ilustrowany jest zdjęciem szkoły pod gołym niebem, które podpisane jest w następujący sposób:

O niskim poziomie życia mieszkańców Afryki świadczą prowizoryczne szkoły pod gołym niebem. (PZ2, 16)

Uogólnienie, jakoby wszystkie szkoły w Afryce były prowizoryczne jest nie tylko stereotypizujące, ale też buduje fałszywy obraz kontynentu, który 
znajduje się na niższym stopniu rozwoju cywilizacyjnego, czego wyrazem jest brak elementarnych form rozwoju infrastrukturalnego. Należy dodać, że $\mathrm{w}$ żadnym $\mathrm{z}$ analizowanych podręczników nie zamieszczono ani jednego zdjęcia afrykańskiego miasta.

Jednym z elementów dyskursu rozwoju cywilizacyjnego jest europocentryzm, czyli rodzaj etnocentryzmu, polegający na przedkładaniu europejskiego punktu widzenia oraz stawianiu europejskiej kultury wyżej innych kręgów kulturowych. Przykładem tej praktyki w analizowanych podręcznikach jest przedstawianie rozwoju krajów Globalnego Południa w kontekście historii kolonializmu, co dobrze ilustrują sąsiadujące przykłady z podręcznika Puls Ziemi 2:

Voodoo to nie tylko religia, ale także rytualne zwyczaje, taniec i styl życia $90 \%$ ludności Haiti - państwa w archipelagu Wielkich Antyli. Voodoo to połączenie wierzeń afrykańskich niewolników, których sprowadzono na wyspę Haiti już na początku XVI w., z elementami katolicyzmu - religii hiszpańskich i francuskich kolonizatorów $(\mathrm{PZ2}, 53)$

Samba (...). W początkach epoki kolonialnej Portugalczycy przenieśli ten zwyczaj na teren dzisiejszej Brazylii. Tam, dzięki indiańskim i afrykańskim niewolnikom, z czasem zabawy te przeobraziły się w jedyny w swoim rodzaju karnawał (...). (PZ2, 53)

Ograniczenie kultury Haiti oraz Brazylii do dziedzictwa kolonialnego jest wyraźnym rozróżnieniem pomiędzy kulturą Północy i Południa. O ile bowiem kultura Północy, przede wszystkim kultura Europy, pokazana jest jako cywilizacyjna ciągłość, której częścią są odkrycia geograficzne, kultura krajów Południa podzielona jest wyraźnie na czas przed oraz po kolonializmie. Ich historia nie ma $\mathrm{w}$ analizowanych podręcznikach ciągłości kulturowej, poza nielicznymi wzmiankami o mieszkającej na ich terytorium rdzennej ludności, zaprezentowanej w kontekście folkloru czy zamieszkiwania w rezerwacie.

Natomiast, niektóre regiony świata przedstawiane są wyłącznie w kontekście europejskiej historii oraz osiągnięć europejskich odkrywców i podróżników. Tak opisano np. Biegun Północny i Biegun Południowy. W rozdziałach im poświęconych znajdują się szczegółowe niekiedy opisy wypraw, ze szczególnym uwzględnieniem polskich podróżników, którzy są jednymi $\mathrm{z}$ niewielu osób wymienionych $\mathrm{w}$ podręcznikach imieniem i nazwiskiem. Historia Biegunów staje się tym samym zapisem wyłącznie europejskiego, w tym polskiego, doświadczenia.

Innym przykładem europocentryzmu może być kwestionowanie religii w krajach Globalnego Południa i podważanie jej zasad: 
Z hinduizmem związany jest też zakaz zabijania "świętych krów” i spożywania ich mięsa. Bezpańskie stada tych zwierząt wałęsają się po miastach i wsiach, co powoduje zakłócenia w ruchu ulicznym. Zwierzęta te, zwłaszcza w miastach, są zaniedbane i wygłodzone. Gdyby hinduizm nie zabraniał spożywania ich mięsa, w znacznym stopniu złagodzony byłby problem niedożywienia w Indiach. (AG2, 147)

Traktowanie innych religii jako niewystarczająco poważne czy nieprawdziwe swoje źródła ma w dyskursie kolonialnym, którego historyczną część stanowił dyskurs misjonarstwa, przedstawiający chrześcijaństwo jako jedyne prawdziwe wyznanie ${ }^{27}$. Wydaje się, że $\mathrm{w}$ przypadku analizowanego fragmentu mamy do czynienia $\mathrm{z}$ podobnym zabiegiem dyskursywnym, w którym znaczenie hinduizmu zostaje umniejszone. Fragment, który najprawdopodobniej ma reprezentować racjonalne, modernizatorskie podejście, przedstawia hinduizm w pozycji nieracjonalnej religii, której zasady są szkodliwe dla ludzi i zwierząt.

W przeciwieństwie do wizerunków Globalnego Południa, w stosunku do krajów Globalnej Północy często stosowana jest pozytywna stereotypizacja, odnosząca się do przekonań o bogactwie Zachodnich Europejczyków i Amerykanów:

Opuszczające niemieckie fabryki samochody odznaczają się wysoką jakością wykonania. Nic zatem dziwnego, że słynący z zamiłowania do aut mieszkańcy RFN zazwyczaj decydują się na zakup samochodu rodzimej produkcji, na przykład luksusowego mercedesa. (PZ2, 187)

Co charakterystyczne, opisy krajów Globalnej Północy wyliczają przede wszystkim osiągnięcia kulturowe i ekonomiczne, w tym listy zabytków oraz obiektów przemysłowych. Podkreślana jest ważna globalnie rola krajów Północy. Na przykład, w podręczniku Planeta Nowa 2, Londyn zostaje określony jako „światowa metropolia” (PN2, 191), Niemcy jako „apteka świata” (PZ2, 187), a Stany Zjednoczone jako „spichlerz świata” (PZ2, 58). Widoczny jest wyraźny brak równowagi pomiędzy przedstawianiem Północy i Południa, gdzie dominuje podkreślanie problemów.

Problemy społeczne Północy, które wymieniają podręczniki, koncentrują się na konsekwencjach rozwoju gospodarczego i przemysłowego, a więc jest to na przykład niski przyrost naturalny, starzenie się społeczeństw, czy zatrucie środowiska. Wszystkie problemy traktowane są jako możliwe do zmiany poprzez racjonalne decyzje ekonomiczne, na przykład:

27 N. Nunn, Christians in Colonial Africa, http://www.econ.yale.edu/ egcenter/Nunn_ Paper.pdf [dostęp: 28.01/2015]. 
Pod względem poziomu rozwoju gospodarczego, Czechy są jednym z liderów wśród byłych państw socjalistycznych. Swoją pozycję zawdzięczają szybko przeprowadzonym reformom rynkowym i znacznym inwestycjom kapitału zagranicznego. (PN2, 209)

Wokół zamkniętych kopalni powstają niekiedy atrakcyjne centra kulturalnorozrywkowe, takie jak Nordstern Park w Geisenkirchen. (PN2, 204)

Problemy Globalnej Północy mogą też zostać sprowadzone do problemów mniejszości narodowych, a więc tym samym przedstawione jako wynikające z procesów migracyjnych:

Liczną mniejszością narodową są Romowie (Cyganie). Wielu z nich to osoby bezrobotne, o niskim poziomie wykształcenia. (PN2, 212)

Brak rąk do pracy i konieczność zatrudniania obcokrajowców (...) może doprowadzić do konfliktów na tle m.in. etnicznym i religijnym. (PZ2, 149)

Ostatnim zagadnieniem, do którego chciałabym się odnieść w tej części tekstu, jest konstruowanie wizerunku Polski względem Globalnej Północy oraz Globalnego Południa.

Należy przede wszystkim zaznaczyć, że wizerunek ten prezentuje nasz kraj jako kulturowo należący do świata zachodniego. Wyraźnie pokazany jest związek Polski z cywilizacją zachodnioeuropejską. Przytoczę obszerny fragment:

Europa, nazywana także Starym Kontynentem, jest dla nas miejscem szczególnym. Rozwój i historia Polski są bowiem nierozerwalnie związane z kształtowaniem się cywilizacji europejskiej. Europejczykami byli m.in. Arystoteles, Ferdynand Magellan, Leonardo da Vinci i Ludwik van Beethoven. Jednym z najważniejszych czynników umożliwiających dynamiczny rozwój cywilizacyjny tej części świata są z pewnością warunki naturalne, które od zawsze sprzyjały działalności człowieka. (PZ2, 135)

Fragment ten ilustruje zabieg powiązania kultury polskiej z kulturą zachodnioeuropejską, którego znaczenie można określić w kontekście dyskursywnego konstruowania tożsamości narodowej ${ }^{28}$. Zabiegi takie wiążą dyskurs narodowy $\mathrm{z}$ określonym katalogiem symboli, w tym wypadku odnoszących się wyłącznie do kultury zachodnioeuropejskiej. Ponadto, powiązany jest on z dyskursem rozwoju cywilizacyjnego, który omówiony został w początkowej części mojej analizy.

${ }^{28}$ M. Popow, The analysis of discursive constructions of national identity in Polish literature textbooks, IARTEM e-Journal, 2014, 2(6). 
Rola Polski w świecie globalnym przedstawiana jest przede wszystkim $\mathrm{w}$ ramach struktur, w których uczestniczy nasz kraj. Charakterystycznym elementem tych przedstawień jest liczne wykorzystanie ilustracji prezentujących globalne instytucje, w których funkcjonuje Polska. Na przykład, w podręczniku Puls Ziemi 3 rozdział „Polska w świecie” ilustrowany jest zdjęciami Parlamentu Europejskiego oraz siedziby ONZ w Nowym Jorku.

Istotne wydaje się również, że Polska zostaje powiązana z historią odkryć geograficznych oraz europejskich podróżników. Widoczne jest to przede wszystkim $\mathrm{w}$ rozdziałach poświęconych Biegunowi Północnemu i Biegunowi Południowemu, w których obszerne miejsce zajmują sylwetki polskich podróżników, przede wszystkim Marka Kamińskiego, który we wszystkich analizowanych podręcznikach jest postacią przedstawioną najbardziej szczegółowo, jedną z nielicznych przedstawionych imieniem i nazwiskiem. Wydaje się, że umieszczenie Polski w tak określonych ramach stanowi element występującego $\mathrm{w}$ podręcznikach dyskursu europocentrycznego, z tym że $\mathrm{w}$ przypadku polskości pełni on rolę określającą przynależność kulturową, a tym samym tożsamość narodową.

Kolejną częścią mojej pracy jest analiza wizerunków mieszkańców Globalnego Południa i Globalnej Północy.

\section{Rodzaj i globalizacja. Wizerunki mieszkańców i mieszkanek Globalnej Północy i Globalnego Południa}

W toku analizy wyraźnie uwagę zwracają wizerunki mieszkańców Globalnej Północy i Globalnego Południa. W rozważanych podręcznikach są one, podobnie jak wizerunki krajów i kontynentów, konstruowane na binarnej osi przeciwieństw pomiędzy Północą i Południem.

Odnośnie wizerunków kobiet i mężczyzn, podobnie jak miało to miejsce w wypadku kontynentów i krajów, można dostrzec wyraźne różnice oparte na konstruowaniu odmienności cywilizacyjnej. Zróżnicowane są, co więcej, nie tylko rodzajowe wizerunki kobiet i mężczyzn, ale również, wewnątrz tych grup, wizerunki kobiet z Północy i Globalnego Południa oraz, odpowiednio, wizerunki mężczyzn. Tak więc, wizerunek kobiecości odnoszący się do Globalnej Północy w rozważanych podręcznikach opiera się na przedstawianiu kobiet pełniących role związane z nauką, pracą, spędzaniem czasu wolnego oraz wypełnianiem funkcji społecznych, przede wszystkim macierzyństwem. Kobiety, których postacie ilustrują rozdziały poświęcone Europie, Ameryce Północnej i Australii przede wszystkim wykonują zajęcia 
związane z uczeniem się. Ich wizerunki ilustrują części podsumowujące rozdziały i testy końcowe. Białe kobiety, przedstawione w podręcznikach, dość często są też turystkami. Podróżują po odległych krajach, zwiedzają zabytki, kąpią się w źródłach termalnych. Często, ale nie zawsze, towarzyszą im mężczyźni.

Z wizerunkiem kobiet Globalnej Północy kontrastuje wizerunek kobiet Globalnego Południa, które przedstawiane są częściej głównie w kontekście ubóstwa, pracy oraz negatywnych zjawisk społecznych. Kobiety kolorowe stanowią ilustracje tekstów na temat ubóstwa, braku dostępu do czystej wody, uchodźstwa, braku infrastruktury, czy wojny. Bardziej szczegółowo chciałabym omówić jednak dwa inne, mniej oczywiste, konteksty, w jakich pojawiają się wizerunki kobiet z Globalnego Południa.

Często pojawiającym się wątkiem, podejmowanym $\mathrm{w}$ podręcznikach, jest kulturowa opresja, jaka dotyka kobiety z Globalnego Południa. Pojawia się on przy omówieniu krajów Bliskiego Wschodu:

W kulturze islamu relacje między rodzicami a dziećmi oraz między mężczyznami a kobietami oparte są na zasadzie podporządkowania (...). Z kolei podporządkowanie kobiet mężczyznom $\mathrm{w}$ wielu krajach oznacza m.in., że żona powinna prosić męża o zgodę na wyjście $z$ domu. Ponadto dziewczęta rzadziej niż chłopcy posyłane są do szkół i wcześniej kończą edukację. W konsekwencji w państwach muzułmańskich wśród dorosłej ludności potrafiącej czytać i pisać jest mniej kobiet. Niewielka jest też aktywność zawodowa kobiet, gdyż ich zatrudnieniu często sprzeciwia się otoczenie. (PZ2, 128)

Tekst ilustruje zdjęcie dwóch kobiet $\mathrm{w}$ czadorach oraz wykres przedstawiający w procentach liczbę kobiet i mężczyzn potrafiących czytać i pisać w Arabii Saudyjskiej, Iranie, Jemenie i Kuwejcie. Mamy tutaj do czynienia z wyraźnym uogólnieniem, które przenosi na wszystkie kraje Bliskiego Wschodu, a nawet na wszystkie kraje muzułmańskie zasady obowiązujące w zdecydowanej mniejszości. Autorzy nie biorą pod uwagę, że świat arabski podlega współcześnie dynamicznym zmianom. Wątek opresji kobiet, ilustrowany kojarzącymi się z naukowością schematami, sąsiadujący często z informacjami dotyczącymi powiązania gospodarki krajów muzułmańskich $\mathrm{z}$ religią oraz ogólnymi informacjami na temat islamu, nie tylko stereotypizuje religię, ale wręcz odsyła do wyraźnych skojarzeń z zacofaniem kulturowym.

Drugim wątkiem jest seksualizacja wizerunków kobiet z Globalnego Południa. O ile kobiety białe ukazane są zawsze w ubraniu, a ich seksualność nie jest eksponowana, kobiety kolorowe często pokazane są w sposób stereotypowy, jako na przykład skąpo ubrane tancerki samby, czy aktorki $\mathrm{z}$ Bollywood. Zabieg ten $\mathrm{w}$ przedstawieniu wizerunku jest typowym zabie- 
giem orientalizacji tamtejszej kobiety, która postrzegana jest poprzez seksualność i to nie własną, lecz wyobrażoną przez świat zachodni29.

Również wizerunek mężczyzn różni się znacząco względem świata, do jakiego przynależą. Mężczyźni Zachodu utożsamiani są przede wszystkim z nauką, rozwojem, zdobywaniem, odkrywaniem. Również czas wolny biali mężczyźni spędzają w sposób najbardziej zróżnicowany - uprawiają sporty, podróżują, dokonują odkryć, pojawiają się również w kontekście polityki (jak np. Polak Jerzy Buzek) oraz w kontekście militarnym, jako żołnierze, uczestnicy misji pokojowych prowadzonych na Globalnym Południu.

W przeciwieństwie do nich mężczyźni kolorowi utożsamiani są z ubóstwem oraz etnicznością (ilustracje przedstawiające np. Aborygenów, plemiona afrykańskie składają się wyłącznie z mężczyzn). Utożsamiani są też z siłą (np. ilustracje oraz tekst dotyczący wyrębu puszczy amazońskiej przedstawiające mężczyzn wyrębujących las piłami mechanicznymi - PN2, 69). Ich wizerunek może być dehumanizowany, czego przykład stanowi ilustracja prezentująca Aborygenów, których portret, jako jeden z symboli Australii, sąsiaduje ze zdjęciem opery w Sydney oraz zdjęciem owiec (PZ2, 76-77).

Mężczyzn z Północy i Południa różni również charakter wykonywanej pracy. Mężczyźni biali najczęściej pokazywani są w sytuacji spędzania czasu wolnego lub pracy zawodowej - są lekarzami, ratownikami, górnikami, hutnikami. Ukazane $\mathrm{w}$ podręcznikach zawody przez nich wykonywane wymagają wysokich kwalifikacji. Tymczasem mężczyźni kolorowi zobrazowani w podręcznikach wykonują prace proste. Ciekawym przykładem w tym kontekście jest opisanie roli tureckich migrantów w Niemczech, o których w jednym z podręczników mówi się:

W Niemczech liczna jest mniejszość turecka. Turcy często zamieszkują osobne dzielnice. $Z$ reguły wykonują prace, które nie wymagają wysokich kwalifikacji. (PN2, 202)

Z powyższego fragmentu można wywnioskować, że Turcy w Niemczech są odizolowaną mniejszością, nieposiadającą wysokich kwalifikacji. Podpisowi towarzyszy zdjęcie przedstawiające Turka pracującego w barze typu kebab. O ile obraz ten może być reprezentatywny dla jakiejś części tej społeczności, z całą pewnością nie jest podstawą do wyciągania wniosków natury ogólnej.

Jeśli chodzi o zaprezentowanie wizerunku i pełnionej roli rodziny, również znacząco odbiegają od siebie. Jako charakterystyczna dla Globalnej Północy, w tym Polski, przedstawiana jest rodzina nuklearna. O modelu rodzi-

${ }^{29}$ Por. E. Said, Orientalizm. 
ny 2+1 mówi się o jako typowym dla współczesnych Europejczyków. Pojawiają się również, choć nieczęsto, rodziny wielopokoleniowe. Prezentacje rodzin białych koncentrują się na przedstawianiu wspólnego spędzania czasu, wspólnych zainteresowań oraz posiłków. Dzieci są zobrazowane wyłącznie w kontekście uczenia się od dorosłych (np. wspólne czytanie z rodzicami, oglądanie mapy) lub uczenia się $\mathrm{w}$ szkole (charakterystyczne są tu wizerunki dziewcząt ilustrujące rozdziały końcowe, w których znajdują się testy sprawdzające).

Często pojawiającym się wątkiem jest związek pomiędzy rozwojem cywilizacyjnym a kontrolowaniem płodności, który $\mathrm{w}$ analizowanych podręcznikach prezentuje fragment:

Na Słowacji żyje najliczniejsza w całej Unii Europejskiej społeczność romska. W wyniku wysokiego przyrostu naturalnego jej liczba wciąż wzrasta. Społeczność tę w znacznej mierze tworzą osoby bezdomne, bezrobotne i słabo wykształcone. (PZ2, 193)

Powyższy fragment można uznać za patologizację procesu rozmnażania się społeczności romskiej, która zostaje powiązana z rozmnażaniem się jednostek uznanych za niepożądane społecznie. Wątek ten odsyła nas to kwestii opisywania problemów społecznych z użyciem dyskursów biologistycznych, ukazujących przypisywanie określonym grupom społecznym cech niepożądanych jako naturalne lub biologicznie im właściwe ${ }^{30}$.

Wielodzietność w podręcznikach zostaje przedstawiona jako cecha negatywna, przyczyniająca się do niskiego statusu społecznego społeczności migranckich oraz przeciwstawiona nuklearnej rodzinie europejskiej. Wprawdzie podręczniki podejmują problem starzenia się społeczeństw w Europie, jednak przedstawiają je w świetle ogólnych zmian dotykających społeczeństwa uprzemysłowione, upatrując rozwiązanie tego problemu oraz jego konsekwencji w braku rąk do pracy, większej płodności migrantów, którym wielodzietność przypisywana jest jako cecha kultury:

(...) Francja przyciąga wielu imigrantów, głównie z byłych kolonii francuskich. Zdecydowaną większość z nich stanowią wyznawcy islamu, w których kulturę wpisana jest wielodzietność. (PZ2, 170)

Na poziomie globalnym rodzina $z$ Południa zostaje przedstawiona jako rodzina z problemami. Żaden podręcznik nie pokazuje pełnej rodziny z Południa, jako że na ilustracjach widzimy zazwyczaj tylko jednego rodzica

30 Por. P. Cohen, It's racism what dunnit'. Hidden narratives in theories of racism, [w:] Race, culture and difference, red. J. Donald, A. Rattansi, Buckingham 1992. 
(najczęściej matkę). I tak, afrykańskie matki oraz towarzyszące im dzieci ukazane są najczęściej podczas wykonywania czynności zapewniających rodzinie podstawowe środki do przeżycia, na przykład wodę (PZ2, 15; PN2, 18), stając się tym samym oddziałującą na emocje ilustracją problemów społecznych całego kontynentu.

Poza dwoma przypadkami, dzieci Globalnego Południa najczęściej obrazują problem sieroctwa, jak pokazane $w$ podręczniku Puls Ziemi 2 dzieci afrykańskie, których zdjęciu towarzyszy następujący podpis:

Na kontynencie afrykańskim mieszka największa liczba dzieci-sierot, których rodzice zmarli na AIDS. (PZ2, 20)

Podpisowi towarzyszy zdjęcie czwórki dzieci w brudnych ubraniach, siedzących na piasku, prawdopodobnie na pustyni. Tego typu przedstawienia dziecięcej biedy $\mathrm{w}$ Afryce, mimo iż $\mathrm{w}$ określonych przypadkach prawdziwe, w podręcznikach stają się jednak jedynym kontekstem, w jakim pojawiają się mali Afrykańczycy.

Jako przeciwieństwo, dzieci z Północy zostały przedstawione w sposób wyidealizowany i mamy wizerunki dzieci zainteresowanych nauką, pilnie uczące się, a przede wszystkim żyjące w pełnych rodzinach. Wszystkie białe dzieci, poza dziećmi romskimi, są zaprezentowane jako szczęśliwe, zdrowe i czyste.

Na zakończenie tej części należy podkreślić, że w podręcznikach nadal stosuje się oparty na kolorze skóry podział ludzi na typy - biały, czarny, żółty i czerwony - używając przeważnie dwóch określeń: rasa i odmiana człowieka. Dodatkowo mówi się o typach mieszanych - Kreolach i Metysach. Tego typu nazewnictwo, podobnie jak wspomniana już kwestia płodności, odsyła do dyskursu biologistycznego, służącego kreowaniu wizerunków grup ludzkich jako z natury odmiennych.

\section{Podsumowanie}

Jak wynika z przedstawionej analizy, wizerunek Globalnej Północy i Globalnego Południa w podręcznikach koncentruje się na binarnych przedstawieniach odmiennych kulturowo, cywilizacyjnie oraz biologicznie obszarów.

Północ i Południe to $\mathrm{w}$ analizowanych podręcznikach dwa odrębne światy, spośród których jeden od początku swojego istnienia wspina się na coraz wyższy poziom rozwoju cywilizacyjnego, drugi natomiast, mniej cywilizowany, pogrążony jest w biedzie i chaosie. 
Zastanawiając się nad społecznym znaczeniem zaprezentowanych tu wizerunków Globalnej Północy i Globalnego Południa, można odnieść wrażenie, że pomimo przeobrażeń, jakie przyniosły ze sobą ruchy antykolonialne oraz dekolonizacyjne, a współcześnie pedagogika krytyczna i emancypacyjna, dyskurs edukacyjny, reprezentowany przez analizowane podręczniki, reprodukuje globalne nierówności.

Dociekając przyczyn takich przedstawień, warto przywołać cytowanego już na początku niniejszej pracy Waltera D. Mignolo, który w eseju The North of the South and the West of the East. A Provocation to the Question dowodzi, że począwszy od XV wieku procesy westernizacji, kolonizacji i dekolonizacji przenikają się nawzajem, bez względu na to, czy świat podzielony jest na Zachód i Wschód, czy też na Północ i Południe ${ }^{31}$. Według Mignolo przekonanie, że kolonialny porządek runął jest ułudą. Rozwijając jego myśl, można stwierdzić, że $\mathrm{w}$ dalszym ciągu jesteśmy pogrążeni $\mathrm{w}$ myśleniu o świecie jako różnych obszarach, dysponujących różnymi możliwościami i prawami, a współczesny kolonializm ma swoje oblicze zarówno kulturowe, jako część procesów globalizacyjnych, oraz ekonomiczne. Wątków tych nie można rozdzielać. Jak pokazuje Arjun Appadurai, współcześnie globalne nierówności są wręcz utrwalane i pogłębione przez globalizację kulturową 32 , w ramach której funkcjonuje kultura masowa, ale i przecież edukacja. W edukacji nierówności globalne reprodukowane są między innymi w określonych typach dyskursu edukacyjnego, co starałam się pokazać w mojej pracy.

Co to oznacza dla myślenia pedagogicznego oraz, szerzej, dla edukacji? Analizowane z perspektywy pedagogicznej wizerunki Globalnej Północy i Globalnego Południa z pewnością nie ukazują uczniom świata w perspektywie różnorodności, sprowadzając zależności globalne do ujęć stereotypowych oraz przedstawiając nierówności jako naturalne i cywilizacyjnie uzasadnione. Przypatrując się analizowanemu materiałowi w świetle założeń edukacji globalnej, zwłaszcza w nurcie globalnego krytycznego obywatelstwa, wydaje się, że raczej utwierdza on, niż rekonstruuje relacje władzy na poziomie globalnym. Utrwala wyobrażenie o Globalnym Południu jako obszarze biednym, niecywilizowanym i zależnym.

Jak wskazują krytyczne teorie edukacyjne, przede wszystkim klasyczna już teoria Paulo Freire, nabywaniu krytycznej świadomości powinno towarzyszyć działanie mające na celu zmianę ${ }^{33}$. Wydaje się, że przyczynkiem do takiej zmiany może być krytyczna rekonstrukcja dominujących wizerunków oraz tożsamości funkcjonujących w ramach dyskursu edukacyjnego, która

\footnotetext{
31 W.D. Mignolo, The North of the South and the West of the East.

32 Por. A. Appadurai, Nowoczesność bez granic. Kulturowe wymiary globalizacji, Kraków 2005.

${ }^{33}$ P. Freire, Pedagogy of the Opressed, New York-London 2005.
} 
jest nieodzownym wstępem do krytycznie rozumianej edukacji globalnej, na bazie której budować można kolejne, coraz bardziej złożone postulaty. W taką też rolę, wstępu do krytycznej analizy dominujących dyskursów i przedstawień w duchu edukacji globalnej, chciałabym wpisać moją analizę.

\section{BIBLIOGRAFIA}

Andreotti V., Soft versus Critical Global Citizenship Education, Global Citizenship, 2006, 3, http://www.developmenteducationreview.com/issue3-focus4 [dostęp: 26.01.2015].

Appadurai A., Nowoczesność bez granic. Kulturowe wymiary globalizacji, przekł. Z. Pucek, Universita, Kraków 2005.

Bauman Z., Globalizacja. I co z tego dla ludzi wynika, Państwowy Instytut Wydawniczy, Warszawa 2000.

Bowżyk J. i in., Edukacja globalna na zajęciach wiedzy o społeczeństwie, Centrum Edukacji Obywatelskiej, Warszawa 2014.

Chapman A., Reflections on a social semiotic approach to discourse analysis in educational research, [w:] Qualitative Educational Research in Education, Routledge, London 2003.

Cohen P., It's racism what dunnit'. Hidden narratives in theories of racism, [w:] Race, culture and difference, red. J. Donald, A. Rattansi, Sage Publications Ltd, The Open University, Buckingham 1992.

van Dijk T., Principles of critical discourse analysis, Discourse \& Society 1993, 4.

Freire P., Pedagogy of the Opressed, Contunuum, New York-London 2005.

Grzybowski P., Tożsamość globalna - kłopoty z poszukiwaniem siebie, [w:] Tożsamość osobowa a tożsamości społeczne, red. T. Bajkowski, K. Sawicki, Wydawnictwo Trans Humana, Białystok 2001.

Grzymała-Kazłowska A., Socjologicznie zorientowana analiza dyskursu na tle wspótczesnych badań nad dyskursem, Kultura i Społeczeństwo 2004, 1(48).

Education for Global Citizenship, Education Above All, Qatar 2012.

Jabłońska B., Krytyczna analiza dyskursu w świetle założeń socjologii fenomenologicznej (dylematy teoretyczno-metodologiczne), Przegląd Socjologii Jakościowej, 2013, 9, 1.

Kielak E., Edukacja globalna w podręcznikach do geografii. Raport z analizy wybranych podręczników szkolnych pod kątem założeń edukacji globalnej, Grupa Zagranica, Warszawa 2014.

Kozielska J., Poakcesyjne migracje zarobkowe. Kontekst teoretyczno-empiryczy. Wsparcie spoteczne, Wydawnictwo Naukowe UAM, Poznań 2014.

Kwieciński Z., Edukacja do globalnego przetrwania i rozwoju, [w:] Tropy - ślady - próby. Studia i szkice z pedagogii pogranicza, red. Z. Kwieciński, Edytor, Poznań-Olsztyn 2000.

Melosik Z., Edukacja globalna: nadzieje i kontrowersje, [w:] Wprowadzenie do pedagogiki: wybór tekstów, red. T. Jaworska, R. Leppert, Oficyna Wydawnicza Impuls, Kraków 1996.

Melosik Z., Teoria i praktyka edukacji wielokulturowej, Oficyna Wydawnicza Impuls, Kraków 2007.

Mignolo W.D., The North of the South and the West of the East. A Provocation to the Question, http://www.ibraaz.org/essays/108/ [dostęp: 23.01.2015].

Müller-Mahn D., Ägyptische Migranten in Paris. Transnationale Migration und die Relativierung des Lokalen, Geographische Rundschau, 2002, 10(54). 
Nunn N., Christians in Colonial Africa, http://www.econ.yale.edu/ egcenter/Nunn_ Paper.pdf [dostęp: 28.01/2015].

Pankowska D., Obraz systemu ról płciowych w podręcznikach szkolnych - analiza porównawcza, Przegląd Badań Edukacyjnych, 2005.

Popow M., The analysis of discursive constructions of national identity in Polish literature textbooks, IARTEM e-Journal, 2014, 2(6).

Said E., Orientalizm, przekł. M. Wyrwas-Wiśniewska, Wydawnictwo Zysk i S-ka, Poznań 2005.

Sapiro M.E., Relatywizm kulturowy i przyszłość antropologii kulturowej, [w:] Badanie kultury. Elementy teorii antropologicznej. Kontynuacje, red. E. Nowicka, M. Kempny, Wydawnictwo Naukowe PWN, Warszawa 2004.

Szkurłat E., Geografia w gimnazjum, [w:] Komentarz do podstawy programowej, [w:] Podstawa programowa z komentarzami, t. 5, Ministerstwo Edukacji Narodowej, Warszawa 2008.

Świderek G., Postaw na rozwój. Zrównoważony! Scenariusze zajęć dla uczniów klas IV-VI szkót podstawowych, Ośrodek Działań Ekologicznych Źródła, Łódź 2013.

Świderek G., O edukacji globalnej i zróżnicowanym świecie, http://www.globalna.edu.pl/ globalnie1/ [dostęp: 26.01.2015].

Warych P., Edukacja globalna wobec problemów wspótczesnego świata, Homines Homnibus, $2012,8$. 